\title{
TAX EXEMPTIONS ON REAL ESTATE TAX IN POLAND
}

\begin{abstract}
The subject of this study is normative analysis of the regulations concerning exemptions from real estate tax heading to assessment of this regulations and proposing solutions de lege ferenda. In the Author's opinion the analysis shows that despite the passage of 25 years since the establishment of municipalities and establishment real estate tax as a source of their incomes tax legal regulations concerning this tax still raise doubts in practice of their application and it's growing. In this study Author described six current problems related to application of the provisions on these exemptions confirm necessity of another amendments of the provisions which by clarifying the regulations will contribute to solve arisen problems. To avoid formation of subsequent problems in future require adopting well-thought-out and stable assumptions about the purposes of which the legislator intends to reach and to take into account the policy of creating law.
\end{abstract}

Keywords: real estate tax; taxation of buildings; structures and lands; tax exemptions; tax reliefs; interpretations of tax law.

\section{Introduction}

The passage of more than 25 years since the establishment of the local government is the right moment for summaries of the functioning of legal regulations concerning tax revenue of municipalities, including local taxes. Despite of the passage of time and subsequent amendments, further problems relating to the application of provisions appear, and one of more current issues of local government in Poland remains the quality of tax regulation. There is also no doubt that since 1990 not only legal regulations concerning local taxes have been changed, but also frequency of verification of correctness of 
the provisions application by the local tax authorities has increased, mainly concerning real estate tax and phenomenon of tax optimization including tax appears on a larger scale.

This increase the number of disputes between taxpayers with local tax authorities, resulting in a growing number of decision challenged to the administrative courts. In the light of the foregoing, it is appropriate to analyse the provisions of real estate tax to the extent that cause doubts, both in practice and doctrine. The subject of this study is normative analysis of the regulations concerning exemptions from real estate tax heading to assessment of this regulations and proposing solutions de lege ferenda.

\section{Characteristics of exemptions in real estate tax}

Analyzed issue requires to describe tax exemptions as legal institutions for the background of ongoing consideration. In theory tax exemptions are defined as an incidental element of tax construction, being a form of reduction of subject or object of the tax ${ }^{1}$.

The definition of 'tax exemption' is also included in regulations of general tax law and associated with the term 'tax relief' concerning in fact another institution. Pursuant to Art. 3 point 6 of the Tax Ordinance Act, by tax relief should be understood provided in the provisions of tax law exemptions, deductions, reductions or diminutions, which implementation cause reduction of taxation base or tax rate. It should be noted that the mentioned provision binds tax reliefs, so also tax exemptions, with the provisions of tax law. By the latter, pursuant to the Article 3 point 2 of the Tax Ordinance Act, we should understand acts regarding taxes, fees and non - tax budgetary receivables, and also issued on their basis executive acts.

When characterizing tax exemptions, we must point out that they are not homogeneous. Different divisions of exemptions are indicated in doctrine ${ }^{2}$, but for the consideration of this study the most important is division on the

1 W. Nykiel, Norma prawa podatkowego a elementy konstrukcji podatku, [in:] J. Małecki, A. Gomułowicz (ed.), Ex iniuria non oritur ius. Ksiega ku czci prof. W. Łączkowskiego, Poznań 2003, p. 235.

2 See ia. W. Nykiel, Ulgi i zwolnienia w konstrukcji prawnej podatku, Warsaw 2002, p. 42 and next. In respect of taxonomy of tax exemptions from real estate tax in other countries see K. Wójtowicz, System opodatkowania nieruchomości w Polsce, Lublin 2007, p. 28-31. 
purpose criterion, which the legislator assumes ${ }^{3}$. Classification of exemption into one of the following types influences in fact on, i.a.: the way of interpretation provisions providing tax exemptions by the administrative courts. First group are the exemptions of 'technical' character, not connected with leaving from the principle of universality and justice in taxation, because their goal is not to 'privilege' any group of taxpayers, but taxation according to the rational model (e.g. income tax exemption of received compensations, which, in fact are the income of the taxpayer, but in terms of economic only compensate loss suffered as a result of the injury). Another distinguished in theory group of exemptions are those whose purpose is to vary the tax burden in order to actually equalizing taxpayers with other entities in other than tax burden areas (e.g. tax exemptions of sheltered workshops, whose main purpose is to enable the trader employing disable people to compete with other entrepreneurs on the market). Third group includes 'typical' tax exemption, i.e.: differentiating situation of taxpayers who are in similar conditions, which aim is to encourage specific behaviours, usually in the area of economic activity.

Relatively large number of exemptions in real estate tax ${ }^{4}$ causes that their presentation, even in synthetic form does not seem to be sesible. We only need to indicate, that the statutory exemption from real estate tax are varied in nature, and are dominated by the subjective - objective exemptions. About preferential treatment of real estate decide mostly social conditions, including, e.g., use of real estate for purposes related to science and education, nature protection etc. The principle is also that occupation for business purposes real property which is exempt from tax, results in losing this exemption. The provisions of Article 7 of the Local Taxes and Fees Act contain regulations on exemptions from real estate tax. The legislator has made at the same time division of the statutory exemptions by placing objective exemptions An Article 7 section 1 of the Act, while in section 2 - subjective exemptions. In addition to the statutory exemptions from real estate tax, the exemption may also result from resolutions of municipal councils issued pursuant to Article 7 section 3 of the Act (these are only objective exemptions), as well as the regulation of other acts. Currently the statutory exemption from the real estate tax are provided in the Article 10 section 1 of the Act of 2 October 2003 of amending the act of special economic zones and certain acts ${ }^{5}$.

See B. Brzeziński, Podstawy wykładni prawa podatkowego, Gdańsk 2008, p. 145-146.

See art. 7 u.p.o.l.

Journal of Laws (Dz.U.) No. 188, item 1840 as amended. 


\section{Problem of interpretation of the provisions concerning exemptions from real estate tax in the judicature}

First current problem regarding application of regulations concerning exemptions from real estate tax is the problem of rules of interpretation of these provisions. In particular, the analysis of the judicature allows us to distinguish two major problems related to the interpretation of the rules governing the exemption from real estate tax, which require characteristics.

In the first place, the problem which we should take into consideration is the position of administrative courts presented consistently to the end of the last decade on the methods of interpretation of the provisions which, in the opinion of the courts should be used in connection with the interpretation of the provisions concerning tax exemptions. In doctrine the attention has been drawn into mistaken way of understanding in judicature of the argument about the need for strict interpretation of tax law in respect of the provisions implementing reliefs and tax exemptions ${ }^{6}$. In theory it is indicated that courts often perceive above-mentioned principle as a directive for interpretation of II degree provisions, which requires in a situation of several possible results of interpretation of provisions governing exemptions to choose the one, which has the narrowest range, due to the fact that is 'strict', and in a result, usually the least beneficial for the taxpayer. In doctrine at the same time lack of grounds for formulation of such assumption of the way of interpretation of tax regulations has been demonstrated ${ }^{7}$. It seems that the correctness of thesis concerning requirement to 'strict interpretation' is especially questionable in the situation of technical nature exemptions and those which aim is to level the situation of taxpayers exempted from tax with other entities. The analysis of judgments confirms acknowledged also in doctrine tendency of the courts, that when they have the ability to select the range of exemption, in case of choosing its narrower meaning, the courts not only settle for granting, that the narrower meaning is the correct one, i.e. relevant to the given case, but also indicate that the choice of this justifies derived from i.a. regulations of the Constitution need for strict interpretation of the provisions concerning exemptions ${ }^{8}$. At the same time, this

B. Brzeziński, Podstawy wyktadni..., p. 142-147.

Ibidem.

$8 \quad$ B. Brzeziński, Podstawy wyktadni..., p. 143. See Judgments of Voivodship Administrative Court (WSA) in Lublin of 21 November 2007 , Ref. no. I SA/Lu 438/07, CBOSA

(Central Database of Administrative Courts Judgments, http://orzeczenia.nsa.gov.pl) and 374 
position seems to lose in significance, what should be taken with approval. Despite the fact that some courts continue to accept them, contemporary judgments on exemptions from real estate tax increasingly not duplicate the formula of exemption as an exception from the principle of the rule of universality, equality and justice of taxation, but through the application of different methods of interpretation the meaning of the provision is settled, often with direct indication on the need to reject strict result of literal interpretation ${ }^{9}$. It is also noted that in current judgements in the area of tax exemptions, it is assumed that in case of interpretation of the concepts there is need to take into account aspects of practical application of the provisions so as to take into account contemporary realities of the economic ${ }^{10}$. Noteworthy is the fact that in some judgments the courts, interpreting the rules, indicate that we cannot abstract from the practical application of the standards, i.e. in the course of teleological interpretation we should particularly take into account social and economic consequences, into which specific understanding of the provision will lead and choose such interpretation, that leads to the most favourable consequences ${ }^{11}$.

Another problem related to the interpretation of the provisions, which requires to be separated for analysis of the judicature, concerns the importance of undefined concepts in the provisions of tax law. In doctrine in relation of using definitions from other branches of law it is claimed that, in principle, they are not binding in the interpretation of tax law. If tax law uses terms, but does not explain them, it is considered that the 'foreign' definitions have the supporting meaning, allowing to find and clarify the general meaning ${ }^{12}$. Definitions from the other branches of law bind always in the situations when they are definitions occurring only in conventional languages (i.e. legal language) ${ }^{13}$. The main problem in the judicature, which was created on the grounds of the aforementioned opinions, is the meaning of the terms which have not been

Voivodship Administrative Court (WSA) in Gdansk of 13 February 2013, Ref. no. I SA/ Gd 1323/12, CBOSA.

9 See judgment of Voivodship Administrative Court (WSA) in Cracov of 8 September 2009, Ref. no. I SA/Kr 1103/09, CBOSA; Judgment of Voivodship Administrative Court (WSA) in Gdansk of 5 February 2013, Ref. no. I SA/Gd 1275/12, CBOSA.

10 Judgment of Supreme Administrative Court (NSA) of 30 October 2009, Ref. no. II FSK 843/08, LEX No. 573490.

11 Judgment of Supreme Administrative Court (NSA) of 29 July 2010, Ref. no. II FSK 729/09.

12 B. Brzeziński, Podstawy wykładni..., p. 74-76.

13 Ibidem, p. 77. 
defined in the Act of Local Taxes and Fees, but in the other acts, including acts not included into tax law. The analysis shows tendency to reach by the courts in the course of interpretation of provisions providing exemptions from real estate tax to definitions from other acts, including other branches of law, despite the fact that there are justified reasons for adopting general meaning ${ }^{14}$.

Assessing the way of interpretation of the rules governing the exemption from real estate tax, it should be stressed that it does not seem that there are reasons for their interpretation using different methods of interpretation from applicable to other provisions or correction of these methods with particular emphasis on one of them. Similarly, as unauthorized should be evaluated modifications in respect of established in doctrine rules of using undefined concepts in tax law.

\section{Taxation of buildings, structures and lands at the airports area}

Pursuant to Article 7 section 1 point 3 of the Act of Local Taxes and Fees, buildings, structures as well as lands occupied for this structures and building at the airside of an airports for the public use shall be exempt from taxation. This Act does not provide tax exemption from real estate tax for lands located at the airside of airport, which were not occupied for the buildings and structures. The interpretation of commented provision may cause doubts as to the meaning of the concept of 'airside of an airport for public use'. The doubts may arise regarding the interpretation of the term 'public use airport'. Because this term in its exact meaning does not occur in everyday language (in common language the concept 'private airport' occurs, which is used to refer these, whose owner is the 'private' entity - in 'non-public' sense - and whose ability to use by other entities is limited by the owner), also in this case it is appropriate to refer to the external systemic interpretation, i.e. to the content of the Article 54 section 1 of the Aviation Law Act, according to which, due to availability for users airports for public use and airports for exclusive use are distinguished. The airport for public use is airport open to all aircrafts within the time and hours limits established by the airport administrator and provided to public information.

14 See B. Brzeziński, Domniemanie języka prawniczego wobec języka powszechnego przy wykładni prawa podatkowego, 'Kwartalnik Prawa Podatkowego', 2011, No. 2, p. 14-16. 
Due to the fact that characterized exemption applies to buildings, structures as well as lands occupied for this structures and buildings at the airside of airport for public use, a doubt arises about whether this objects should be actually used for the activities of the public airport, or whether the function itself is sufficient. In accordance with the judgment of the WSA (Voivodship Administrative Court) in Olsztyn, of 4 September $2008^{15}$, characterized exemption refers to specific subject - airside of airport for public use. In the assessment of the Court it cannot be inferred from this legal regulation that airport, which that area is part of must be in public use in sense of actual functioning and public accessibility, to talk about the exemption from real estate tax. Tax exemption should be made then, when exists such object, as defined in the aviation law airside of airport for the public use, regardless of whether it is actually used for the purposes for which it has been designated and approved. Real estate will therefore benefit from the exemption, although the owner of the airport will not have authorization from the President of the Civil Aviation Office for operating airline business. Notwithstanding the abovementioned thesis we should stress at the same time, that according to the article 2 point 4 of the Act - Aviation Law, the requirement for the existence of airport is entry to register of airports, which is constitutive in nature ${ }^{16}$, buildings and structures exemption will be able to apply from next day after the entry.

\section{Exemption from tax farm buildings or their parts}

Pursuant to the Article 7 section 1 point 4 of the Local Taxes and Fees Act, farm buildings or their parts serving for forestry or fishing activities, located at the farm lands, for exclusively agricultural activities and engaged for running special departments of agricultural production shall be exempt from real estate tax.

The glossary of the Act defines the concept of the building, but analyzed exemption was limited to 'farm buildings', which is the term that the Act does not define. Therefore, the importance of meaning of this concept arises at this point, including in particular, possibility of using definition from the other branches of law, including construction law, geodesic and cartographic law.

15 I SA/Ol 164/08, CBOSA.

16 R. Dowgier, L. Etel, B. Pahl, M. Popławski, Leksykon podatków i opłat lokalnych, Warsaw 2010 , p. 288. 
We should also stress that the term 'farm building' is a term used commonly in everyday language and according to the meaning assigned to him, this is the type of building separated from others, in terms of function it holds ${ }^{17}$.

The buildings or parts of buildings situated on farm lands, for exclusively agricultural activities are subject of exemption from real estate tax. In the event of applying of the provision for taxation exemption of buildings or parts of them which are situated on farm lands, for exclusively agricultural activities, administrative courts uniformly assume, usually not justifying this view in a wider way that the farm buildings which take advantage of the exemption must be located on agricultural land which are agricultural holding in the meaning of the Article 2 section 1 of the Agricultural Tax Act. In accordance with that provision, as an agricultural holding shall be considered an area of agricultural land with a total area exceeding 1 hectare or 1 conversion hectare, owned or held by the taxpayer ${ }^{18}$. It should be noted that the definition of the agricultural holding referring to standard scheme 1 hectare contains also the Article 2 section 2 of the law of 11 April 2003 Act on the Agricultural System ${ }^{19}$. As long as, however, the interpretation that indicates the need to adopt in the course of interpreting the meaning of term 'agricultural holding' on the basis of the definition of the Agricultural Tax Act was clearly justified before 1 January 2003, so at the time, when the applicable provisions of commented Act contained references to other applicable provisions, in current legal circumstances lack of such reference causes that in the light of the principles of interpretation of tax law we should use definitions from common language. It should be pointed that except of aforementioned definition of the agricultural holding from the Agricultural Tax Act, the definition of the agricultural holding includes also article $55^{3}$ of the Civil Code, but it does not anticipate the requirement of territorial norms existence, but stresses need for existence of components related to the agricultural economy constituting unity. It also appears that this civil law definition is closer to the meaning, which is suitable for the term 'agricultural holding' in everyday language i.e. without taking into account the requirement of the area of land and stressing its necessary function ${ }^{20}$.

17 M. Szymczak, (ed.), Stownik Języka Polskiego. Tom I, Warsaw 1978, p. 213 and 613.

18 Judgment of Supreme Administrative Court (NSA) of 20 September 2013, Ref. no. II FSK 2564/11, CBOSA.

19 Consolidated text, Journal of Laws (Dz.U.) 2012, item 803.

20 See also B. Brzeziński, Podstawy wykładni..., p. 71-72. 


\section{Buildings and structures occupied by a group of agricultural producers}

Pursuant to Article 7 section 1 point 13 of the Act on Local Taxes and Fees, exempt from real estate tax are buildings and structures occupied by a group of agricultural producers entered in the register of these groups, used solely to conduct business in sale of products or groups of products produced in the agricultural holdings of the members of the group or in the extent specified in Article 4 section 2 of the Act of 15 September 2000 on the groups of agricultural producers and their associations and on amendments to other acts ${ }^{21}$, in accordance with its founding act. The condition of exemption from tax of buildings and structures is to occupy them by a group of agricultural producers entered in the register of these groups. Pursuant to Article 2 section 1 of the Act on agricultural producer groups and their associations and on amendments to other acts, natural persons, organizational entities without legal personality and legal entities, which, in the framework of their agricultural activity run:

1. agricultural holding in the meaning of agriculture tax provisions,

2. special department of agricultural holding.

- can organize themselves in the groups of agricultural producers in order to adapt agricultural products and the production process to the market requirements, jointly launching goods into the market, including preparation for sale, centralization of sales and supply to wholesalers, establishing common rules concerning information about production with particular regard to harvesting and availability of agricultural products, developing business skills, marketing and organizing and facilitating innovation processes implementation as well as protection of the environment. The entry in the register of producer groups shall be done by Marshal of the province who is competent for the registered office of the Group.

In accordance with the judicature, characterized exemption does not apply to every producing group entered into any register of these groups (including e.g. register kept under the Act of 19 December 2003 on the organization of the markets of fruit and vegetables and the market of hops ${ }^{22}$ ). Since the legislator indicates the 'groups of agricultural producers' and record of these groups, then there is no reason to extend the exemption to other producer groups, including

21 Journal of Laws (Dz.U.) No. 88, item. 983 as amended.

22 Consolidated text, Journal of Laws (Dz.U.) 2011, No. 145, item 868 as amended. 
recognized groups of fruit and vegetable producers (judgment of the Voivodship Administrative Court (WSA) in Poznan 10 September 2015. ${ }^{23}$ ).

The abovementioned regulation excluding possibility of use the exemption of other production groups than entered into the register referred to in the Act is incomprehensible and violating discrimination ban.

\section{Sheltered workshops}

Pursuant to Article 7 section 2 point 4 of the Act of Local Taxes and Fees, exempt from real estate tax are administrators of sheltered workshops that meet the condition referred in Article 28 section 1 point 1 letter $b$ of the Act of 27 August 1997 on the vocational and social rehabilitation and employment of disable persons $\mathrm{Act}^{24}$, or vocational rehabilitation centers in respect of objects of taxation reported to marshal, if report has been confirmed by decision on granting sheltered workshop or vocational rehabilitation center status or certificate - occupied to run this workshop, except objects of taxation held by dependent entities not being administrators of sheltered workshops that meet the condition referred in Article 28 section 1 point 1 letter $b$ of the Act of 27 August 1997 on the vocational and social rehabilitation and employment of disable persons Act, or vocational rehabilitation centers.

Problem appears in the situation concerning exempt of the taxpayer administrating sheltered workshop from real estate tax occupied for the sheltered workshops' needs in situation, when except taxpayer there are other co-owners of the real estate not administrating sheltered workshop, but the entire property is occupied for the purposes of the sheltered workshop. In a situation where there at least two co-owners of real estate, Article 3 section 4 on the Local Taxes and Fees Act is applied, according to which if the real estate or construction is joint ownership or is in the possession of two or more entities, this is a separate object of taxation, and real estate or construction tax obligation encumber jointly and severally all co-owners or possessors. Pursuant to Article 91 of the Tax Ordinance Act, to joint and several liability for tax obligation, the provisions of the civil code on civil law obligations are applied. Pursuant to Article 366 of the Civil Code, several debtors may be obliged in such a manner that the creditor may demand the whole or part of a performance from all the

23 I SA/Po 100/15, CBOSA, pronouncement delay.

24 Journal of Laws (Dz.U.) 2011, No. 127, item 721, as amended. 
debtors jointly, from several of them, or from each of them individually and satisfaction of the creditor by any of the debtors releases the other debtors. Seemingly interpretation of the provisions leads to the conclusion that the exempted from real estate tax is sheltered workshop but the same tax will pay jointly and severally obliged co-owner.

At this point it is worth to draw attention to the judgment of the Supreme Administrative Court (NSA) of 3 April 2014 (II FSK 968/12, CBOSA), in which it is rightly acknowledged that aforementioned interpretation is faulty due to the fact that it is not only contrary to the purpose of the provision, but does not take into account the fact of the solidarity of tax liability. Properly interpreted provision should be as resulting in described situation with exempt from real estate tax of the whole area occupied by entities employing disable people.

\section{Objective exemptions arising from the resolutions of municipal councils}

Pursuant to Article 7 section 3 of Local Taxes and Fees Act, municipal council, by resolution, may implement other objective exemptions than those specified in section 1 and in Article 10 section 1 of the Act of 2 October 2003 amending the Act on special economic zones and certain acts.

Content of that provision indicates the possibility of implementing by resolutions subjective exemptions only. Inconsistent with the statutory mandate will be therefore implementation both subjective and mixed: subjective - objective exemptions. This opinion, regarding subjective exemptions in a narrow way, shall be regarded as settled in the administrative courts judicature. The exemption resulting from resolution cannot therefore relate to the subject, or the nature of the business, but only to the object of taxation, that is, the property held by the taxpayer. This is justified by the fact that Article 217 of the Constitution of Poland stipulates that subjective exemptions can be determined solely by acts. Meanwhile, the exemption referred in Article 7 section 3 of Local Taxes and Fees Act, are determined by the resolutions of municipal council on the grounds of Article 18 section 2 point 8 of the 
Municipal Government $\mathrm{Act}^{25}$. For the same reasons, there will not be also possible to exclude in the resolution possibility of using implemented exemption specified in it group of entities.

The doubt arises concerning determination of the object of exemption in a way that actually results in its application to specific entities. In the opinion of the courts it is necessary to specify in the resolution exempted object in such a way that it is not possible to identify specific taxpayer. The features of the object must be defined so as to apply to potentially (hypothetically) unmarked individual taxpayer. The courts recognize that in any case, whenever directly from established standards can be inferred, who shall be exempted, and not only the object which shall be exempted, exemption can be subjectively objectively by nature, and this consequently means exceeding the statutory delegation from Article 7 section 3 of Local Taxes and Fees Act ${ }^{26}$. Therefore, municipal council by exempting, for example, municipal assets de facto releases from real estate tax against the law specific assets of the entities listed in that provision, which held rights in the extent referred there to pointed in that provision object of the taxation ${ }^{27}$. Similarly in judicature are treated regulations of the resolutions, in which as exempted real property object (building, land and construction) is pointed, and then narrows the exemption to those that are i.a. property of companies and local government legal person or are held by the government and self-government organizational units. Administrative courts emphasize that range of exemptions, cannot be modified i.a. by subjective criteria relating to the sources of income of persons covered by the exemption ${ }^{28}$.

Lack of possibility for introducing exemptions of subjective - objective nature and restrictive way of understanding by the courts 'subjective - objective' exemption are criticized by representatives of the municipalities due to impediments in conducting effective tax policy.

25 Judgment of Supreme Administrative Court (NSA) of 3 December 2014, Ref. no. II FSK 2833/12, CBOSA.

26 Judgment of Supreme Administrative Court (NSA) of 23 October 2014, Ref. no. II FSK 2592/12, CBOSA.

27 Judgment of Supreme Administrative Court (NSA) of 14 August 2007, Ref. no. II FSK 909/06, CBOSA.

28 Judgment of Voivodship Administrative Court (WSA) in Wroclaw of 18 November 2005, Ref. no. I SA/Wr 881/05, CBOSA. 


\section{Summary}

The analysis shows that despite the passage of 25 years since the establishment of municipalities and establishment real estate tax as a source of their incomes tax legal regulations concerning this tax still raise doubts in practice of their application. It seems that, despite the subsequent amendments to the Local Taxes and Fees Act range of those doubts is still growing. This is particularly evident in case of real estate tax exemptions. Described in this study current problems related to application of the provisions on these exemptions confirm necessity of another amendments of the provisions which by clarifying the regulations will contribute to solve arisen problems. To avoid formation of subsequent problems in future require adopting well-thought-out and stable assumptions about the purposes of which the legislator intends to reach and to take into account the policy of creating law.

\section{Literature}

1. Brzeziński B., Domniemanie języka prawniczego wobec języka powszechnego przy wykładni prawa podatkowego, 'Kwartalnik Prawa Podatkowego'. 2011, No. 2, p. 14-16.

2. Brzeziński B., Podstawy wykładni prawa podatkowego, Gdańsk 2008.

3. Dowgier R., Etel L., Pahl B., Popławski M., Leksykon podatków i opłat lokalnych, Warsaw 2010.

4. Nykiel W., Norma prawa podatkowego a elementy konstrukcji podatku, [in:] J. Małecki, A. Gomułowicz (ed.), Ex iniuria non oritur ius. Księga ku czci prof. W. Łączkowskiego, Poznań 2003.

5. Nykiel W., Ulgi i zwolnienia w konstrukcji prawnej podatku, Warsaw 2002.

6. Szymczak M., (ed.), Stownik Języka Polskiego. Tom I, Warsaw 1978.

7. Wójtowicz K., System opodatkowania nieruchomości w Polsce, Lublin 2007.

Pawel Majka

University of Rzeszow 